\title{
Intelligent Irrigation Control System by Employing Wireless Sensor Networks
}

\author{
Prakashgoud Patil \\ B.V.B. College of Engineering and Technology \\ Hubli - 580031, Karnataka, India
}

\begin{abstract}
Fast growing technology of wireless sensor networks (WSN) is an advantage to the agriculture sector. Modern advances in the development of WSN offer new trends like Precision Agriculture (PA). This paper presents Fuzzy Logic Based Intelligent Irrigation Control System by employing WSN for PA. In the proposed system the irrigation controller normalizes the desired moisture level in the agricultural soil by controlling the water flow of the irrigation pump based on the sensor readings, by switching the pump between $\mathrm{ON}$ and OFF states. For the efficient utilization of water in the agricultural irrigation, the proposed methodology offers a system equipped with soil moisture sensors, temperature sensors, precise irrigation equipments, computer-controlled devices, and an intelligent controller using fuzzy logic approach for irrigation of agricultural fields, which simulates or emulates the human being's intelligence. This leads to effective utilization of various resources like water and electricity and hence becomes a cost effective system for the expected yield. The fuzzy controller designed in this paper efficiently monitors moisture level in soil, leaf wetness, temperature, humidity, and other essential parameters and also controls the irrigation intelligently. The results show that the application is correct and reasonable and enables user to precisely acquire the crop water requirement information. The system can be effectively applied to PA applications such as water-saving agriculture areas, for example, the croplands, the nursery gardens and the greenhouses.
\end{abstract}

\section{Keywords}

Intelligent Irrigation Control System, Fuzzifier, Fuzzy Rules, Inference Engine, Precision Agriculture (PA), Wireless Sensor Networks.

\section{INTRODUCTION}

From the past, agriculture has been playing an important role in human societies to suffice the growing and dynamic demands. Irrigation is an essential component of crop production in many areas of the world. PA is an integrated system designed to increase long-term, field-specific, and farm production efficiencies, productivity, and profitability in the field of agriculture. The PA is very essential for the countries like India whose agriculture completely depends upon the rains and climatic conditions. Precision farming ensures quicker response times, better quality control for the yield with a minimum labor effort. There is a requirement for use of sensing technologies in the field of PA to monitor the crop parameters and control the utilization of resources towards the societal benefits [1].

In the field of agriculture, use of proper method of irrigation and its control is important. Automation of irrigation system has the potential to provide maximum water use efficiency by monitoring soil moistures and other crop parameters at optimum level. In conventional irrigation system, the farmer has to keep watch on irrigation time-table, which is different

\author{
B.L.Desai \\ B.V.B. College of Engineering and Technology \\ Hubli - 580031, Karnataka, India
}

for different crops and dependent on type of soil and other parameters [8]. The farmers manually control the water supply to the crop-fields according to the time-table or experientialjudgment. This process sometimes consumes more water or sometimes water reaches late due to which crop gets dried up. Irrigation has traditionally resulted in excessive labor and non uniformity in water application across the field. Hence an automatic irrigation system based on sensing technology is required to reduce the labor cost and to give uniformity in water application across the field [3].

\section{MOTIVATION FOR THE WORK}

WSN technology has broad applications in many areas because of its advantages such as low-cost equipment, safe and reliable data transfer, simple and flexible network and easy deployment. The implementation of precise control irrigation for crop water demand information is one of the important ways to improve the utilization of water. WSN has proved to be useful in applications that involve monitoring of real-time data. In order to optimize the yield and the use of the available resources, wireless sensor networks can play a relevant role because of their ability of providing real-time data collected by spatially distributed sensors.

\section{IRRIGATION CONTROLLER TYPES}

Irrigation is the manual application of water for growing crops. In crop production it is mainly used in dry areas and during shortage of rainfall to protect crops. There are different types of irrigation such as Surface irrigation, Localized irrigation, Drip irrigation and Sprinkler irrigation. In the field of agriculture, use of proper method of irrigation and its control is important.

Two general types of controllers are used to control irrigation systems: Open control loop systems and Closed control loop systems. Open control loop systems apply a preset action, such as is done with simple irrigation timers. Closed control loops receive feedback from sensors, make decisions and apply the results of these decisions to the irrigation system.

\subsection{Open Loop System}

In an open loop system, the operator makes the decision on the amount of water that will be applied and when the irrigation event will occur. This information is programmed into the controller and the water is applied according to the desired schedule. Open loop control systems use either the irrigation duration or a specific applied volume for control purposes. Open loop controllers normally have a clock that is used to start irrigations. Termination of the irrigation can be based on a pre-set time or may be based on a specified volume of water passing through a flow meter. Open loop control systems are typically low in cost and readily available from a variety of vendors. They vary in design and complexity and often offer flexibility as to the number of zones and how irrigations are scheduled. The drawback of open loop systems is their inability to respond automatically to changing conditions in the environment. In addition, they may require 
frequent resetting to achieve high levels of irrigation efficiency [2].

\subsection{Closed Loop System}

In closed loop systems, the operator develops a general control strategy. Once the general strategy is defined, the control system takes over and makes detailed decisions of when to apply water and how much water to apply. This type of system requires feedback from one or more sensors. Irrigation decisions are made and actions are carried out based on data from sensors. In this type of system, the feedback and control of the system are done continuously. Closed loop controllers require data acquisition of environmental parameters (such as soil moisture, temperature, radiation, wind-speed, etc) as well as system parameters (pressure, flow, etc.). The state of the system is compared against a specific desired state, and a decision whether or not to initiate an action based on this comparison. Closed loop controllers typically base their irrigation decisions on the sensors that measure soil moisture, temperature, humidity and evaporation and other climatic data to estimate water requirement of a crop [2].

\section{IMPLEMENTATION OF SYSTEM HARDWARE}

This section presents proposed Fuzzy based Irrigation Control System architecture using WSN for monitoring and controlling the irrigation in an agriculture which is as shown in Figure 1. It consists of four basic components namely [A] Wireless Sensor Network [B] Gateway Node / Sink Node [C] Fuzzy based Irrigation Controller [D] Irrigation Pipe Network.

The first component consists of Wireless Sensor Network which sense physical and environmental parameters and send data to the gateway node. Second component is application server which receives data from gateway and processes it. The last component is irrigation pipe network which is laid over the irrigated areas and the electric control valves are installed on pipelines.

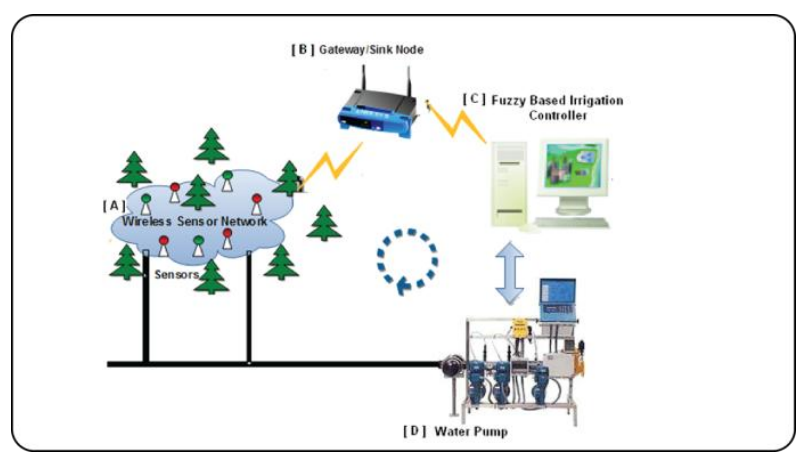

Figure1. Fuzzy Based Irrigation Controller System Architecture

\subsection{Wireless Sensor Network:}

The proposed system implemented using the MEMSIC eKo Pro Series which is a wireless agricultural and environmental sensing system for crop monitoring. The system also provides an easy deployment of wireless monitoring system in an agricultural layout for efficient collection of data about its needs from multiple locations.

The eKo Node is a fully integrated, rugged outdoor sensor package that uses an energy-efficient radio and sensors for extended battery-life and performance. The eKo Node integrates MEMSIC's IRIS processor/radio board and antenna that are powered by rechargeable batteries and a solar cell. An eKo Node is capable of an outdoor radio range up to 2 miles depending on the deployment and the hardware configuration chosen. The nodes themselves form a wireless mesh network that can be used to extend the range of coverage. By simply

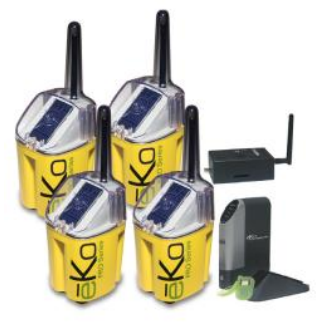
adding an additional eKo Node, it is easy to expand the coverage area. The nodes come preprogrammed and configured with MEMSIC's XMesh low-power networking protocol. This provides plug-and-play network scalability for wireless sensor networks. The system can be easily enhanced with various sensors such as soil moisture, ambient temperature and humidity, leaf wetness, soil water content, solar radiation, etc.[7]

\subsection{Sensors For Precision Agriculture}

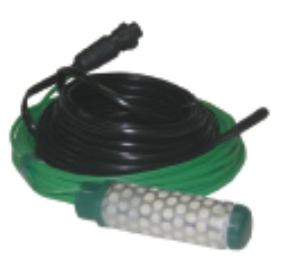

Soil Moisture and Temperature: The ES1100 Watermark Sensor (granular matrix sensor) is a soil moisture and soil temperature sensor. Up to four ES1100 sensors can be connected to one eKo Node to measure soil moisture at different soil depths. By monitoring the sensor measurements between irrigations, it is possible to measure the rate at which the soil is drying out [7].

Soil Water Content: The ES1110 uses the Decagon EC-5 which obtains volumetric water content by measuring the dielectric constant of the media through the utilization of capacitance/ frequency domain technology. It incorporates a high frequency oscillation which allows the sensor to accurately measure soil moisture in any soil with minimal salinity and textural effects.

Ambient Temperature and Humidity: The ES1201 is a

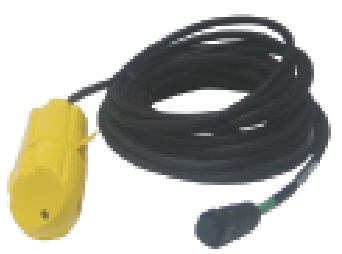
temperature/humidity sensor that measures the ambient relative humidity and air temperature. These readings are also used to calculate dew point. The sensor enclosure protects the sensor from mechanical damage, and a membrane filter protects the sensor elements from dust, dirt,

and water spray[7].

Leaf Wetness Sensor(LWS): Leaf wetness sensor from Decagon. Many fungal and bacterial diseases affect plants

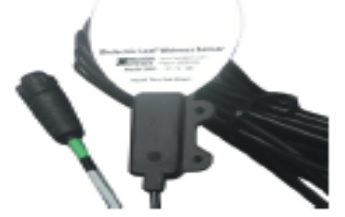
only when moisture is present on a leaf surface. The leaf wetness determines the presence and duration of canopy wetness allowing users to forecast disease and protect the plant canopy. The LWS outputs 445 raw counts when dry. When the sensor is totally 
wet, as in a heavy rain, the signal can range up to around 1400 counts. Varying amounts of water on the surface of the sensor cause a sensor output proportional to the amount of water on the sensor's surface. The figure 2 shows the sample raw output from LWS sensor [11].

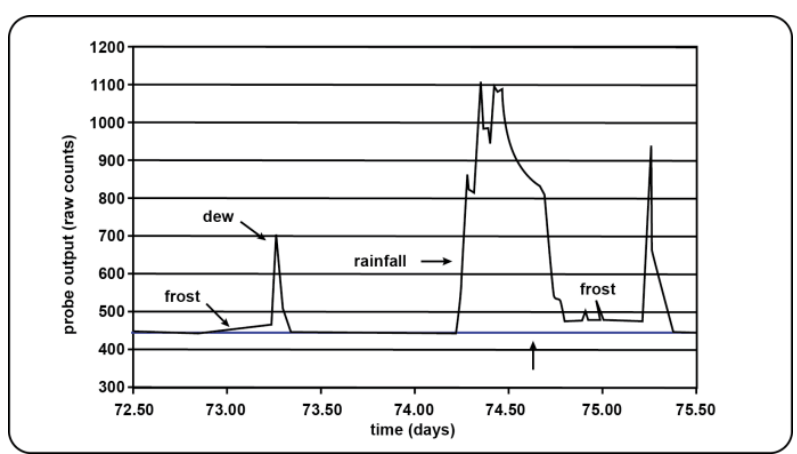

Figure 2: Sample raw output from the LWS

\subsection{Fuzzy Logic Theory}

Fuzzy Logic Control (FLC) system is based on fuzzy set theory. This set theory is advanced version of classical set theory called crisp theory. In crisp set theory, an element either belongs to or does not belong to a set. But fuzzy set supports a flexible sense of membership of elements to a set. Many degrees of membership, between 0 and 1, are allowed. The membership function is associated with a fuzzy set in such a way that the function maps every element of the universe of discourse or the reference set to the interval $[0,1]$. In crisp logic, the truth values acquired by propositions or predicates are two-valued, namely TRUE or FALSE which may be treated numerically equivalent to $(0,1)$. However, in fuzzy logic, truth values are multi valued such as absolutely true, partly true, absolutely false very true, and so on and are numerically equivalent to any value in the range 0 to $1[3]$.

In general, a Fuzzy Logic System (FLS) is a nonlinear mapping of an input data vector into a scalar output. Figure 3 depicts a FLS that is widely used in fuzzy logic controllers. A FLS maps crisp inputs into crisp outputs, and this mapping can be expressed quantitatively as $y=f(x)$. It contains four components: fuzzifier, fuzzzy rules, inference engine, and defuzzifier[3].

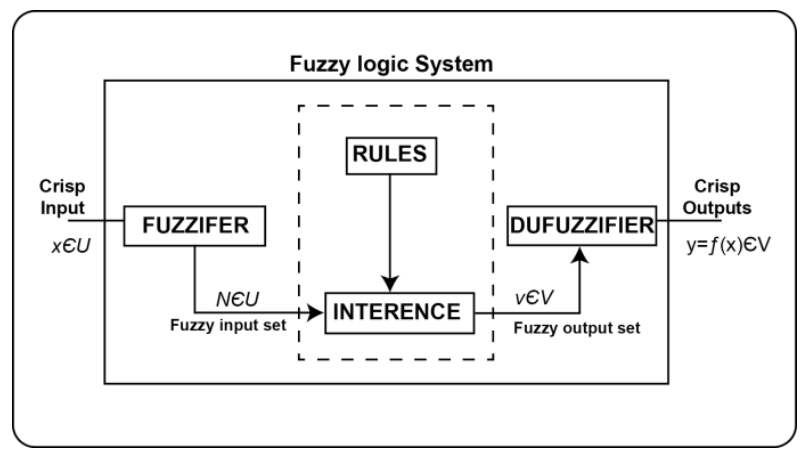

Figure 3: The structure of FLC system

Fuzzy logic allows inclusion of expert knowledge in control system. A fuzzy logic system contains sets used to categories input data (fuzzification), decision rules that are applied to each set, and a way of generating an output from the rule results (defuzzification). Inference unit is the core of the fuzzy controller. It generates fuzzy control actions applying the rules in the knowledge base to the current process state. It determines the degree to which each measured valued is a member of a given labeled group.

\subsection{Design of Fuzzy Controler}

The agricultural crops like all other plants have different growth stages and hence their water requirements (intake) vary accordingly. For an adequate yield required amount and timely supply of water should be assured to support the physiological activities taking place within the crop [4]. The details of various parameters used in our proposed work are explained below.

\subsection{Irrigation Parameters for Efficient System Operation}

To ensure proper design and operation of an irrigation system, the following parameters should be considered.

i) Rooting Depth of the crop.

ii) Sand Texture \& Water Storage Capacities of Soil

iii) Water Usage Capabilities based on the type of crop

iv) Field Soil Moisture Content

v) Leaf Wetness, Environment Temperature and Relative Humidity

In designing the Fuzzy Logic Controller (FLC) following 5 steps are to be followed.

Step 1: Identification and Declaration of Inputs and Output:

In the first step, we have identified inputs and outputs and linguistic variables. The process of declaring the values of input and output called universe of discourse and are as shown in the following table 1-7.

\begin{tabular}{|c|c|c|c|}
\hline \multicolumn{4}{|c|}{ Membership Function } \\
\hline Crop Name & $\begin{array}{l}\text { Rooting } \\
\text { Depth }\end{array}$ & $\begin{array}{l}\text { Linguistic } \\
\text { Variable }\end{array}$ & Range \\
\hline $\begin{array}{l}\text { Cabbages, } \\
\text { Cauliflowers, } \\
\text { Clover (Ladino), } \\
\text { Cucumbers, } \\
\text { Lettuce, Onions, } \\
\text { Pasture, Grasses, } \\
\text { Radishes, Turnips }\end{array}$ & $1.5 \mathrm{ft}$ & Shallow & {$\left[\begin{array}{lll}0 & 0 & 1,1.5\end{array}\right]$} \\
\hline $\begin{array}{l}\text { Beans, Beets, } \\
\text { Blueberries, } \\
\text { Broccoli, Carrots, } \\
\text { Celery, Potatoes, } \\
\text { Peas, Strawberries }\end{array}$ & $2.0 \mathrm{ft}$ & $\begin{array}{l}\text { Medium } \\
\text { Shallow }\end{array}$ & {$[11.5,2,2.5]$} \\
\hline $\begin{array}{l}\text { Brussels Sprouts, } \\
\text { Cereals, Clover } \\
\text { (Red) Corn } \\
\text { (sweet), Eggplant, }\end{array}$ & $3.0 \mathrm{ft}$ & $\begin{array}{l}\text { Medium } \\
\text { Deep }\end{array}$ & {$[2,2.5,3,3.5]$} \\
\hline
\end{tabular}




\begin{tabular}{|l|l|l|l|}
\hline $\begin{array}{l}\text { Kiwifruit, } \\
\text { Peppers, Squash }\end{array}$ & 4.0 ft & Deep & {$[3,3.5,4,4.5]$} \\
\hline $\begin{array}{l}\text { Alfalfa, } \\
\text { Asparagus, } \\
\text { Blackberries, } \\
\text { Corn, Grapes, } \\
\text { Loganberries, } \\
\text { Raspberries, Sugar } \\
\text { Beets }\end{array}$ & $>4 \mathrm{ft}$ & $\begin{array}{l}\text { Heavy } \\
\text { Deep }\end{array}$ & {$[4,4.5,5]$} \\
\hline $\begin{array}{l}\text { Mango Tree \& } \\
\text { other Tree Fruits }\end{array}$ & & & \\
\hline
\end{tabular}

Table 2 provides values on the available water storage capacities (AWSC) of various soils. The AWSC is the amount of water that can be stored in the soil against the force of gravity. As the soil texture becomes finer, more water can be stored. Plants are capable of extracting only a portion of the water from the soil before being stressed.

\begin{tabular}{|c|c|c|c|c|}
\hline Soil Texture & $\begin{array}{c}\text { AWSC } \\
{[\operatorname{lnch}(W) /} \\
\text { Foot(S)] }\end{array}$ & $\begin{array}{c}\text { AWSC } \\
{[\operatorname{Inch}(} \\
\text { W)/Foo } \\
t(S)]\end{array}$ & $\begin{array}{c}\text { Linguisti } \\
\text { c } \\
\text { Variable }\end{array}$ & Range \\
\hline Sand & 1 & \multirow{3}{*}{1} & \multirow{3}{*}{ Sandy } & \multirow{3}{*}[\begin{array}{llll}{0}&{0}&{1}&{1.5}\end{array}]{} \\
\hline Loamy Sand & 1.2 & & & \\
\hline Sandy Loam & 1.5 & & & \\
\hline $\begin{array}{l}\text { Fine Sandy } \\
\text { Loam }\end{array}$ & 1.7 & \multirow{3}{*}{2} & \multirow{3}{*}{ Loamy } & \multirow{3}{*}[\begin{array}{llll}{1}&{1.5}&{2}&{2.5}\end{array}]{} \\
\hline Loam & 2.1 & & & \\
\hline Silt Loam & 2.5 & & & \\
\hline Clay Loam & 2.4 & \multirow{3}{*}{3} & \multirow{3}{*}{ Clay } & \multirow{3}{*}[\begin{array}{llll}{2}&{2.5}&{3}&{3.5}\end{array}]{} \\
\hline Clay & 2.4 & & & \\
\hline $\begin{array}{l}\text { Organic Soils } \\
\text { (muck) }\end{array}$ & 3 & & & \\
\hline
\end{tabular}

Table 3 indicates availability coefficient to determine the maximum percentage of water that may be removed before irrigation is again required for a crop.

\begin{tabular}{|l|c|c|c|}
\hline \multicolumn{4}{|c|}{ Table 3: Availability Coefficient to Determine Plant Water } \\
Use Capabilities \\
\hline \multicolumn{1}{|c|}{ Crop Name } & $\begin{array}{c}\text { Plant Water } \\
\text { Use } \\
\text { Capabilities } \\
(\%)\end{array}$ & $\begin{array}{c}\text { Linguistic } \\
\text { Variable }\end{array}$ & Range \\
\hline $\begin{array}{l}\text { Peas, Potatoes... } \\
\text { Gree Fruits, } \\
\text { Tomatoes... }\end{array}$ & 15 & Low & {$\left[\begin{array}{llll}0 & 0 & 10 & 15\end{array}\right]$} \\
\hline Other crops... & 35 & Medium & {$\left[\begin{array}{llll}10 & 15 & 20 & 25\end{array}\right]$} \\
\hline
\end{tabular}

Table 4 indicates Soil Moisture Content sampled from Soil moisture sensor. Water content or moisture content is the quantity of water contained in the soil called soil moisture. The soil moisture measurement device, or sensor, shall represent soil moisture status in units of soil water tension or metric potential, registering in centibars (cb) or kilopascals $(\mathrm{kPa})$ when read with a compatible reading device.

\begin{tabular}{|c|c|c|c|}
\hline Soil Moisture & $\begin{array}{c}\text { Soil } \\
\text { Moisture } \\
\text { Level } \\
\text { (CentiBars) }\end{array}$ & $\begin{array}{c}\text { Linguistic } \\
\text { Variable }\end{array}$ & Range \\
\hline \multirow{4}{*}{$\begin{array}{l}\text { Soil Moisture } \\
\text { Sensor Reading } \\
\text { obtained from } \\
\text { field }\end{array}$} & 10 & Saturated & {$\left[\begin{array}{llll}0 & 0 & 6 & 12\end{array}\right]$} \\
\hline & 20 & $\begin{array}{l}\text { Adequately } \\
\text { Wet }\end{array}$ & $\begin{array}{l}{\left[\begin{array}{lll}6 & 12 & 18 \\
24\end{array}\right]} \\
\end{array}$ \\
\hline & 30 & Normal & $\begin{array}{l}{\left[\begin{array}{lll}18 & 24 & 30 \\
36\end{array}\right.}\end{array}$ \\
\hline & 40 & Dry & $\begin{array}{l}{\left[\begin{array}{lll}30 & 36 & 60 \\
60\end{array}\right.}\end{array}$ \\
\hline
\end{tabular}

Table 5 indicates the Environment Temperature in Degree Centigrade obtained from the temperature sensor. 


\begin{tabular}{|c|c|c|c|}
\hline $\begin{array}{l}\text { Environment } \\
\text { Temperature }\end{array}$ & $\begin{array}{l}\text { Environment } \\
\text { Temperature }\end{array}$ & $\begin{array}{c}\text { Linguistic } \\
\text { Variable }\end{array}$ & Range \\
\hline \multirow{5}{*}{$\begin{array}{l}\text { Environment } \\
\text { Temperature } \\
\text { in Degree } \\
\text { Centigrade } \\
\text { obtained from } \\
\text { Temperature } \\
\text { Sensor }\end{array}$} & 10 & Very Cold & {$\left[\begin{array}{llll}0 & 0 & 10 & 15\end{array}\right]$} \\
\hline & 20 & Cold & {$\left[\begin{array}{llll}10 & 15 & 20 & 25\end{array}\right]$} \\
\hline & 30 & Normal & {$\left[\begin{array}{llll}20 & 25 & 30 & 35\end{array}\right]$} \\
\hline & 40 & Hot & {$\left[\begin{array}{lllll}30 & 35 & 40 & 45\end{array}\right]$} \\
\hline & 45 & Very Hot & [40 45 450 50] \\
\hline
\end{tabular}

Table-6 indicates the Relative Humidity. Relative humidity is the percentage of maximum water content at a given temperature. Most growers work with relative humidity expressed in \%. A good indication of air humidity would be the absoluter humidity in $\mathrm{g} / \mathrm{m} 3$ but horticulturist usually works with relative humidity $(\mathrm{RH})$ in percents. $\mathrm{RH} 100 \%$ means extremely humid condition and for instant $50 \%$ indicated very dry air conditions.

\begin{tabular}{|c|c|c|c|}
\hline $\begin{array}{r}\text { Table } 6 \\
\end{array}$ & $\begin{array}{l}\text { vironment } \\
\text { centage ob }\end{array}$ & $\begin{array}{l}\text { lative Humi } \\
\text { led from Se }\end{array}$ & $\begin{array}{l}\mathrm{r}(\mathrm{RH}) \text { in } \\
\mathrm{r}\end{array}$ \\
\hline $\begin{array}{l}\text { Relative } \\
\text { Humidity } \\
\text { Sensor } \\
\text { Reading }\end{array}$ & $\begin{array}{c}\text { Relative } \\
\text { Humidity } \\
(\%)\end{array}$ & $\begin{array}{c}\text { Linguistic } \\
\text { Variable }\end{array}$ & Range \\
\hline \multirow{4}{*}{$\begin{array}{l}\text { Environment } \\
\text { Relative } \\
\text { Humidity in } \\
\text { percentage } \\
(\%)\end{array}$} & 10 & Low & {$\left[\begin{array}{llll}0 & 0 & 10 & 20\end{array}\right]$} \\
\hline & 20 & Medium & {$\left[\begin{array}{lllll}10 & 20 & 30 & 40\end{array}\right]$} \\
\hline & 30 & High & {$\left[\begin{array}{lllll}30 & 40 & 50 & 60\end{array}\right]$} \\
\hline & 40 & $\begin{array}{c}\text { Extremely } \\
\text { High }\end{array}$ & {$\left[\begin{array}{llll}50 & 60 & 60 & 60\end{array}\right]$} \\
\hline
\end{tabular}

The Table 7 indicates the normal range of the readings obtained from Leaf wetness Sensor (LWS) usually the output is measured in $\mathrm{mV}$ ranges between 100-1500 mV @ 3V excitation. LWS is a leaf-wetness sensor that can detect small amounts of water or ice on the sensor surface. It is designed to be deployed either in the canopy or on a weather station mast.

\begin{tabular}{|c|c|c|c|}
\hline $\begin{array}{c}\text { Leaf } \\
\text { Wetness } \\
\text { Sensor } \\
\text { Reading }\end{array}$ & $\begin{array}{c}\text { Leaf } \\
\text { Wetness }\end{array}$ & $\begin{array}{c}\text { Linguistic } \\
\text { Variable }\end{array}$ & Range \\
\hline \multirow{5}{*}{$\begin{array}{l}\text { Leaf } \\
\text { Wetness } \\
\text { Obtained } \\
\text { from Sensor }\end{array}$} & 100 & Wilting & {$\left[\begin{array}{lllll}0 & 0 & 200 & 300\end{array}\right]$} \\
\hline & 400 & Normal & [200 300400500$]$ \\
\hline & 500 & Frost & [400 500600700$]$ \\
\hline & 700 & Dew & [600 700800900$]$ \\
\hline & 1000 & Rainfall & $\begin{array}{l}{[8009001400} \\
1400]\end{array}$ \\
\hline
\end{tabular}

Step 2: Identification of Control Surfaces: In this step, the linguistic variables are identified and membership values for each linguistic variable are calculated. The input and output variables are represented by fuzzy membership functions as shown in figure 4-8.

Step 3: Behavior of Control Surfaces: Fuzzy rules are constructed to specify action for different conditions. The fuzzy rules associate the fuzzy output from fuzzy inputs. The rule base for the said application is shown in Figure 11. 


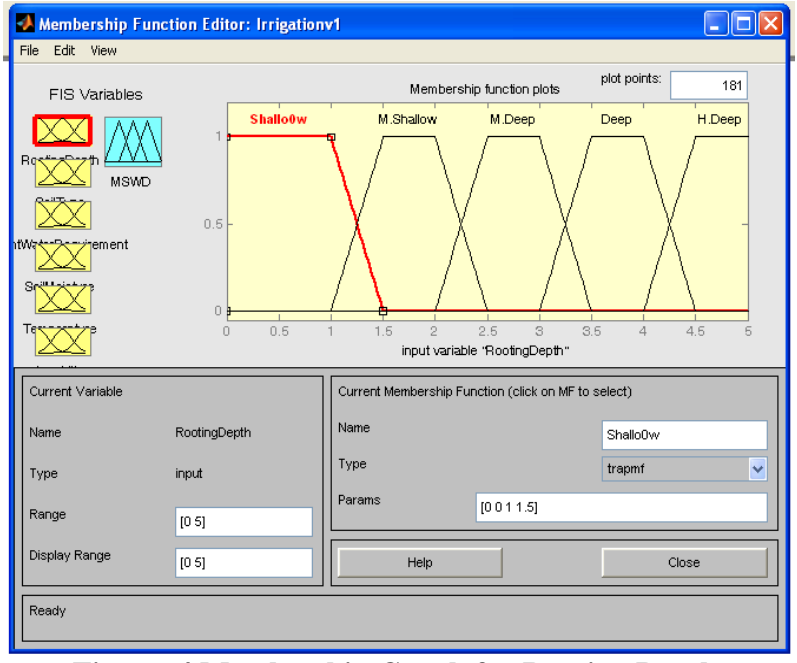

Figure 4 Membership Graph for Rooting Depth

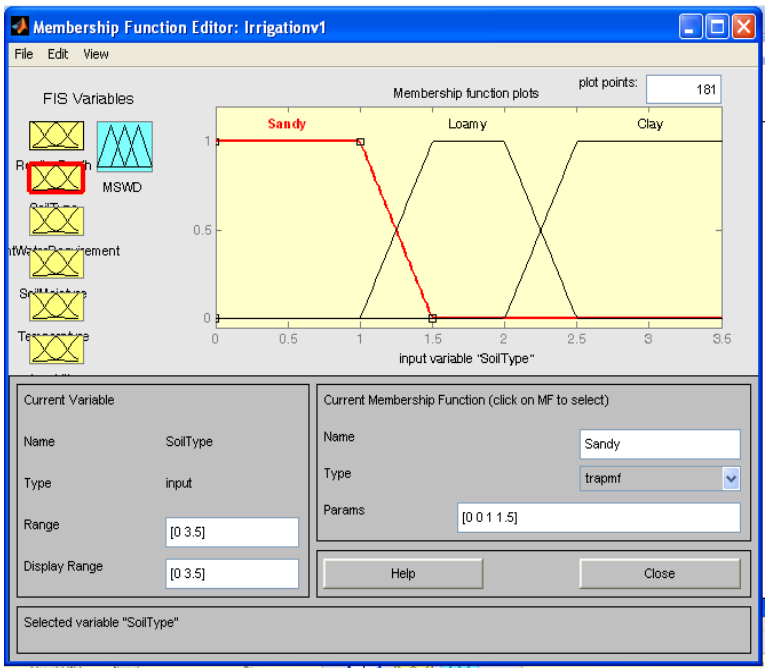

Figure 5. Membership Graph for Soil Type

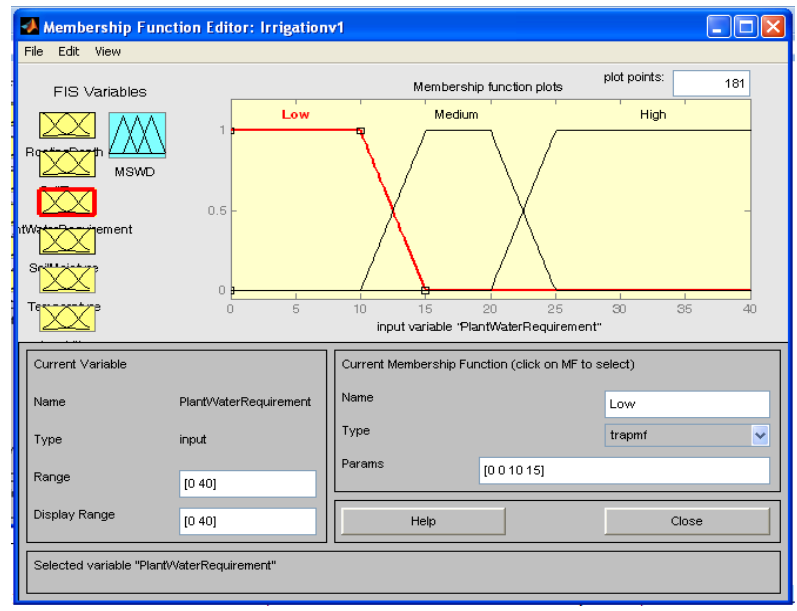

Figure 6 Membership Graph for Plant Water Use Capability

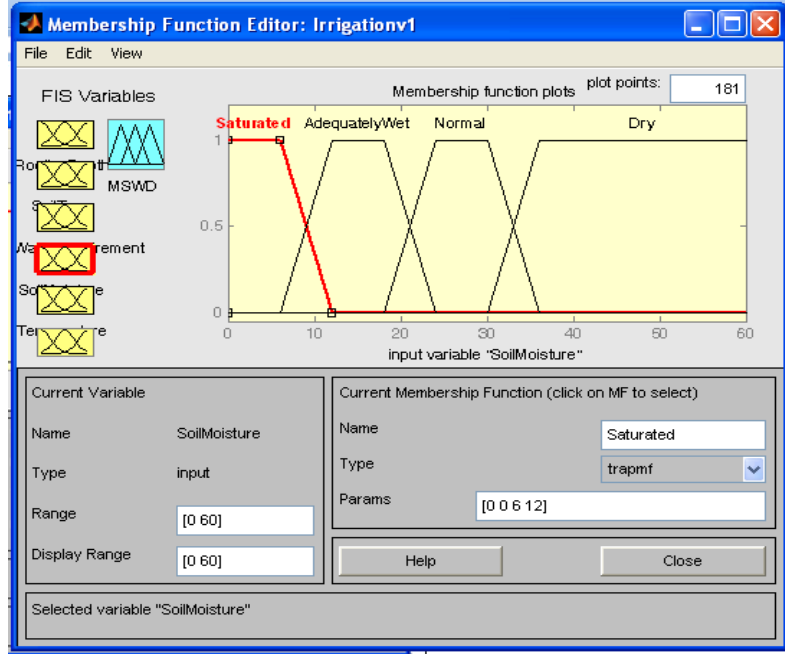

Figure 7 Membership Graph for Soil Moisture

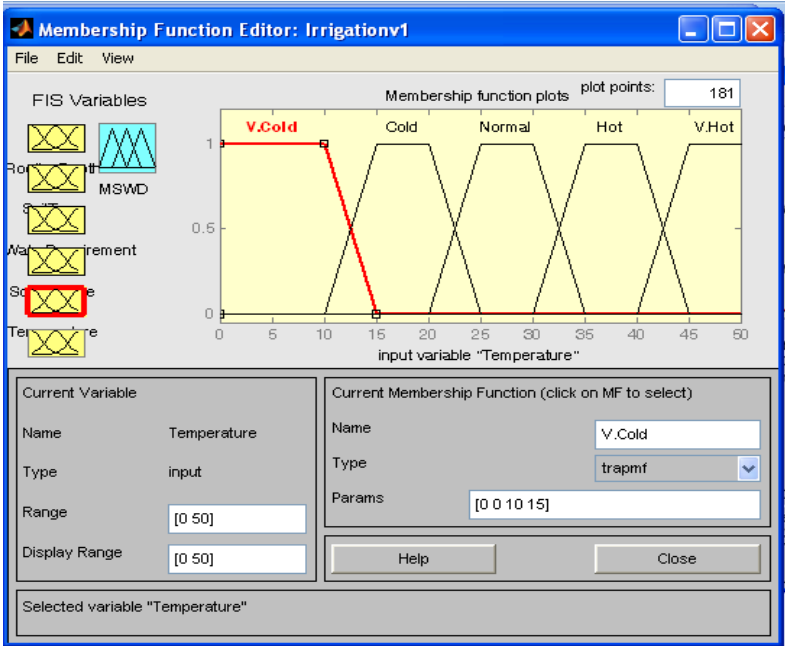

Figure 8 Membership Graph for Temperature

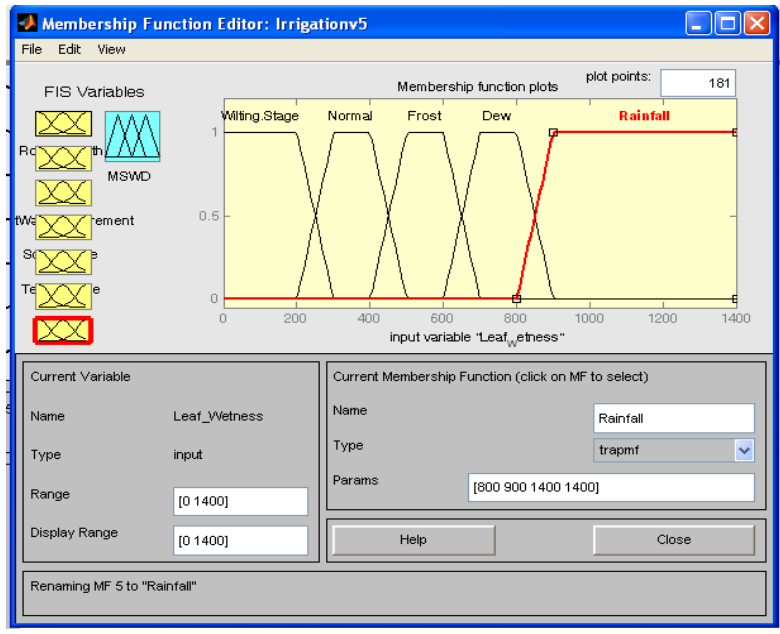

Figure 9 Membership Graph for Leaf Wetness 


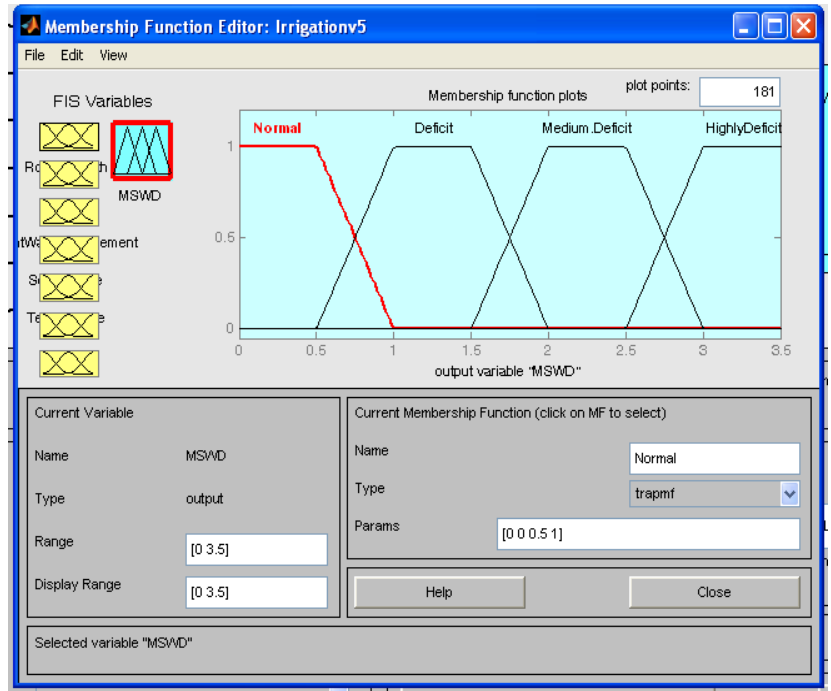

Figure 10 Membership Graph for Fuzzy Output

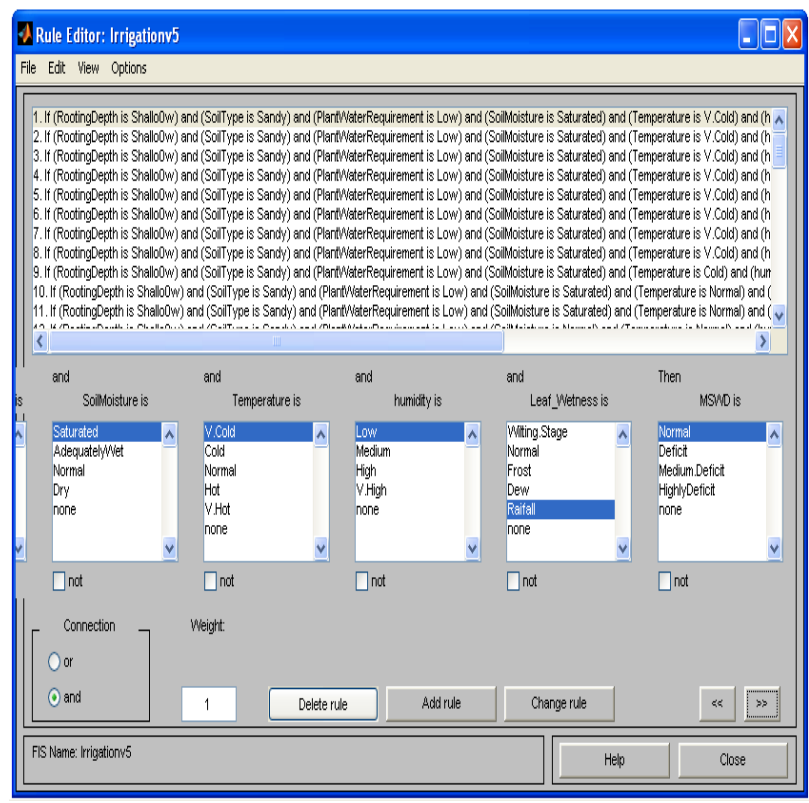

Figure 11 Fuzzy Rule Base for Irrigation Controller

STEP 4: Fuzzy Inference System and Decision Making: The fuzzy inference system consists of fuzzy rules (IF antecedent THEN consequent) that are devised by an expert knowledge base or through system input-output learning. Gaussian, triangle, and trapezoid functions are the most commonly used membership functions. In the fuzzy rules, triangular and trapezoidal-shaped membership functions are used for the variables to simplify the computations. The core of fuzzy system is this rule base system which mimics human reasoning. The most commonly used fuzzy inference technique is Mamdani method. Fuzzy rule base drives the inference system to produce fuzzy outputs, which are defuzzified to get system outputs. In this case, we have considered 7 input variables and each consists of fuzzy linguistic variables.

Step 5: Defuzzification - The transformation from a fuzzy set to a crisp number is called defuzzification. For any given crisp input value, there may be fuzzy membership in several input variables, and each will cause several fuzzy outputs cells to fire or to be activated. This brings the process of defuzzification of output to crisp value. There are many kinds of defuzzification methods, usually maximum membership and centroid techniques are used. In practice, defuzzification is done using centroid method.

\section{RESULTS AND DISCUSSION SULTS}

This work has been carried out using MATLAB simulation tool. The developed software for the proposed work was tested under different input condition and provided good results in terms of accuracy and has a wide scope of being established in near future. The results obtained by the proposed system and estimated numerical methods are tabulated for the purpose of comparative studies.

Maximum Soil Water Deficit (MSWD): MSWD is the maximum moisture that can be removed from the soil before irrigation is again required. The soil type and depth and crop rooting depths must be determined to calculate MSWD.

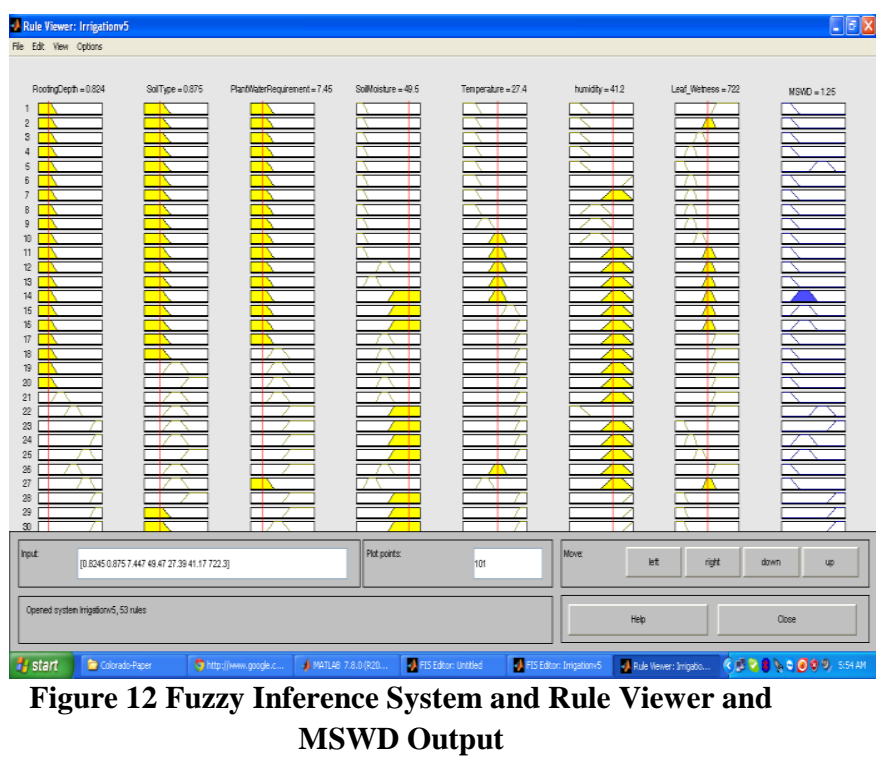

Numerical Method:

Example 1:

What is the maximum soil water deficit of a mature tree fruit crop growing in $2 \mathrm{ft}$. of sand underlain by $3 \mathrm{ft}$ of sandy loam?

a. Table 1: Effective rooting depth $=4 \mathrm{ft}$

b. Table 2:

$\mathrm{AWSC}=$

$2 \mathrm{ft}$ sand @ $1.0 \mathrm{in} / \mathrm{ft}$

$=2.0 \mathrm{in}$

$2 \mathrm{ft}$ sandy loam @ $1.5 \mathrm{in} / \mathrm{ft}=3.0$ in

$\underline{\text { Total }=5.0 \mathrm{in}}$

c. Table 3 Availability coefficient $=40 \%$

d. $\quad$ MSWD. $=5.0$ in $\times 0.40=2.0$ in

e. The gross amount to be applied $=[$ MSWD / Application Efficiency $]=2.8$ inches $=$ (i.e. 2.0 in $/ 072=2.8$ )

Note: Sprinkler irrigation system Application Efficiency efficiencies are usually considered to be $72-75 \%$ with good management while a trickle irrigation system may be $90 \%$.

f. Maximum Interval $=[$ MSWD $/$ Peak E.T. rate $]=\quad[$ 2.0in $/ 0.20 \mathrm{in} /$ day $]=10$ days 
g. Application rate can be calculated by: A.R. = gpm (U.S.) x 96.3 / [S1 x S2]

h. Where the application rate is in inches/hr and the sprinkler spacing (S1 and S2) are in feet.

\begin{tabular}{|c|c|c|c|c|c|}
\hline 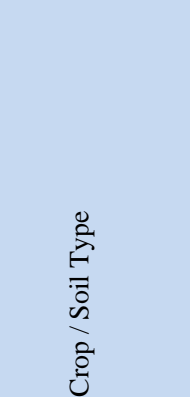 & 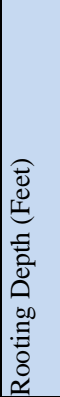 & 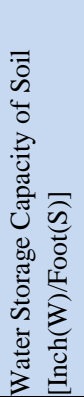 & 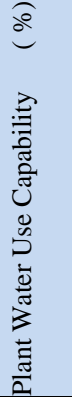 & 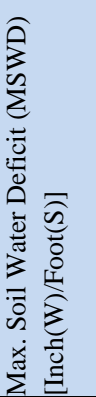 & 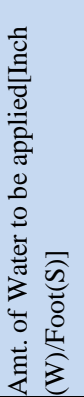 \\
\hline & A & B & $\mathrm{C}$ & $\begin{array}{c}\mathrm{D} \\
(\mathrm{BXC})\end{array}$ & \\
\hline Cabbage/Sand & 1.5 & 1 & 0.35 & 0.35 & 0.46 \\
\hline Cabbage/Loam & 1.5 & 1.7 & 0.35 & 0.595 & 0.79 \\
\hline Cabbage/Clay & 1.5 & 2.4 & 0.35 & 0.84 & 1.12 \\
\hline $\begin{array}{l}\text { Tree Fruit } \\
\text { /Sand }\end{array}$ & 4 & 1 & 0.4 & 0.4 & 0.53 \\
\hline $\begin{array}{l}\text { Tree Fruit } \\
\text { /Loam }\end{array}$ & 4 & 1.7 & 0.4 & 0.68 & 0.90 \\
\hline Tree Fruit /clay & 4 & 2.4 & 0.4 & 0.96 & 1.28 \\
\hline
\end{tabular}

By applying the fuzzy logic system, the results which were already observed which shows that this method requires less amount of water for the same yield when compared to the method followed by the traditional farmer. Thus the result shown above ensures the effectiveness and accuracy of our proposed system.

\section{CONCLUSION \& FUTURE WORK}

Crop irrigation control is the most important concern in the domain of agriculture. Shortage of water globally is also emphasizing the need of systems that not only control the crop irrigation but also provide the intelligent way to provide water to only those places where it is needed and in the required quantity. By monitoring soil moisture, Leaf Wetness, Temperature and Relative Humidity and by taking into consideration the other parameters like plant root depth, Sand Texture \& Water Storage Capacities of Soil, Plant Water Use Capabilities one can make efficient use of water resources and also in achieving high yield. The work presented here brings out the potential advantages of applying FLC technique for Irrigation System. The simulation result provides an exact idea for water output for the prescribed agricultural field.
Thus we conclude that, by using the proposed technique, we get the following advantages - Increasing Irrigation Efficiency, Reducing the Labor cost, Saving water and electricity. In extended versions the better results can be obtained by taking into other factors like evapo-transpiration etc.

\section{ACKNOWLEDGMENT}

The authors would like to thank Dr. Ashok Shettar, Principal, B.V.B College of Engg., \& Tech for the valuable support and motivation for our work.

\section{REFERENCES}

[1] British Columbia, A Ministery of Agriculture and Food, IRRIGATION PARAMETERS FOR EFFICIENTSYSTEM OPERATION - A Fact Sheet, 1998

[2] Brian Boman, Steve Smith, and Bill Tullos, Control and Automation in Citrus Microirrigation Systems, University of Florida.

[3] Domingo Gómez-Melendez, Fuzzy irrigation greenhouse control system based on a field programmable gate array,African Journal of Agricultural Research Vol. 6(11), pp. 2544-2557, 4 June, 2011

[4] Edward C. Martin, Methods of Determining When to Irrigate Cooperative Extension, College of Agriculture \& Life Sciences, The University of Arizona

[5] ENVIRONMENTAL OPTIMIZATION OF IRRIGATION MANAGEMENT WITH THE COMBINED USE AND INTEGRATION OF HIGH PRECISION SATELLITE DATA, ADVANCED MODELING, PROCESS CONTROL AND BUSINESS INNOVATION, Version - issue date: 1.2 - 30/05/2012

[6] Hal Werner, Extension irrigation engineer, Measuring Soil Moisture for Irrigation Water Management, Cooperative Extension Service

[7] http://www.memsic.com/products/wireless-sensornetworks.html (eKo Pro Environmental Monitoring System manual)

[8] Jumman A and Lecler NL, "A continuous soil water potential measurement System for irrigation scheduling assessment", Proceedings of South African Sugarcane Technology Association, pp. 608-612, 2009.

[9] M. Cogan. "Water measurement in soil and vines". Vineyard \& Winery Magazine, vol.28, No3, USA. 2002.

[10] P. R. Dry, "Irrigation deficit strategies for maximizing water use and wine quality in Australia". Journal Int. des Sciences de la Vingen et du Vin 35, 2005.

[11] http://manuals.decagon.com/Manuals/10386_Leaf\%20W etness\%20Sensor_Web.pdf 